Revista Eletrônica Geografar, Curitiba, v. 2, Resumos do VI Seminário Interno de Pós-Graduação em Geografia, p. 27-27. Junho/2007

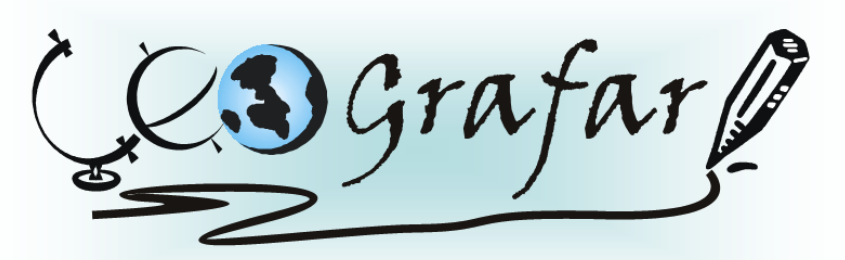

Revista Eletrônica do Programa de Pós-Graduação em Geografia - UFPR

\title{
PROPOSTA DE PARCELAMENTO DO SOLO E OCUPAÇÃO DA ILHA DOS VALADARES NO MUNICÍPIO DE PARANAGUÁ
}

\author{
FELIPE AUGUSTO HOEFLICH DAMASO DE OLIVEIRA ${ }^{1}$
}

Localizada na planície litorânea do estado do Paraná, mais precisamente no município de Paranaguá, a Ilha dos Valadares tem a sua ocupação ligada aos ciclos econômicos pelo qual passa a cidade. Dessa maneira, de acordo com o crescimento da cidade a população da ilha teve um acréscimo. Por outro lado, na Ilha dos Valadares, se encontram dois ecossistemas ambientalmente frágeis, o manguezal e a restinga, que tiveram suas áreas ocupadas por uma população que no ano de 2000 atingiu 11.466 habitantes (cerca de 9\% da população de Paranaguá). Tendo em vista este panorama, uma nova proposta de ocupação e parcelamento do solo da ilha se faz necessário, pois a ocupação de áreas ambientalmente frágeis pode acarretar sérios impactos ao meio ambiente (como erosão, alagamentos, assoreamento dos cursos de água e contaminação de nascentes), bem como prejudicar a qualidade de vida da população ali presente. Para a elaboração de uma nova proposta de parcelamento do solo e ocupação da Ilha dos Valadares, um diagnóstico que leve em consideração as suas características físicas (como clima, vegetação natural, geologia, pedologia, hidrografia) e sociais (demografia, aspectos econômicos, aspectos sociais, aspectos culturais) é necessário. Esse diagnóstico que relaciona os aspectos físicos com os sociais é de suma importância para a compreensão da dinâmica entre a sociedade e o meio ambiente nessa área. Segundo essa dinâmica, levando em consideração as potencialidades físicas do local e as necessidades da sociedade que o ocupa, a proposta de parcelamento e ocupação do solo será efetuada, tendo em vista uma melhora na qualidade de vida da população e da condição dos ecossistemas frágeis que o cercam.

Palavras-Chaves: parcelamento do solo; ocupação da Ilha dos Valadares; diagnóstico sócio ambiental.

${ }^{1}$ Mestrando em Geografia - UFPR - email: felipeaugusto@ufpr.br Orientadora: SONY CORTESE CANEPARO 